\title{
THE REFLECTION OF THE GLOBAL CAPITALISM SYSTEM IN SUZANNE COLLINS'S THE HUNGER GAMES
}

\author{
${ }^{1}$ Muhammad FadhlyThahir, ${ }^{2}$ Fathu Rahman, ${ }^{3}$ Mustafa Makka \\ ${ }^{123}$ English Language Studies Program, Faculty of Cultural Sciences, \\ Hasanuddin University, Makassar \\ muh.fadhly.thahir@gmail.com \\ fathu.rahman@unhas.ac.id \\ mustafa_makka@yahoo.com
}

\begin{abstract}
The aim of this research is to describe the reflection of the global capitalism system in Suzanne Collins's novel The Hunger Games. This research also explains on how the influences between The Hunger Games with the portrait of the global capitalism in the world. The research uses qualitative descriptive methods trough sociology of literature theory. It focuses on the relation of intrinsic elements in the literary works with the reality aspect from the society. The data constitute both primary and supporting data. The primary data was taken from the novel itself The Hunger Games, while supporting data are taken from books, theses, journal and articles from internet which related to the topic of the research. The result of research shows that The Hunger Games novel represented the global capitalism system in many ways. The differences between Capitol and all districts considered as the symbol of capitalism system where the rich get richer and the poor get poorer. The government of Panem which stayed in Capitol can be easily to control and dictated the people across the countryside. The global capitalism system in the novel reflected through the way of government of Panem control the economic side, market value, and political side.
\end{abstract}

Key words: The Hunger Games, sociology of literature, reflection, global capitalism system

\section{INTRODUCTION}

Generally, literary works can be divided into four parts such as novel, short story, drama play, and poetry. Novel refers to the literary or written form by people in length volume and large size of story. Short story also refers to the literary or written form but in short volume and small size of story. Poetry is the art of poets, poems in many kinds like ballads, epics, etc. Drama is play with its actress and actor and its scene of dialogues, conversation, tragedies, comedies, and so on. As the social animals, people are needs to understand their position, condition and their wants. As a part of society, people should be aware that many people around needs to carrying and knowing each others. It means the structure of the society should be known well for every people. All of human activities are affected by the interplay between social structure and individual.
There was no people in the world can be life alone without any help, communication, and interaction with other people. All of them understood as the human wants and the role of social activity in the social life. Nowadays, the author creates many works of literature in the form of classical literature and modern or popular literature. One of the famous novels in recently era is the trilogy novel The Hunger Games by Suzanne Collins. The Hunger Games is a novel about a sixteen years old girl, Katniss Everdeen who lives in a post apocalyptic nation of Panem where it was once known as North America. She lives in a dystopia society which then leads her to fight for rebellion to the totalitarian leader.

The Hunger Games as one of many popular novels which give us an overview of the bleak and terrible future due to the human actions itself. This popular novel 
presents different vision to make people nowadays realize that there is a possibility of this future can be happen one day. Popular literature is important to empower the reader to be inspired to make a difference to be better people. The writers of popular literature try to give a vision to the readers the possibility of different future, human have choice whether to choose what kind of future would they have, it all depends on the human itself. Politics and economics are two important elements of human life that having a big influences to the social life. Politics are known as the element which organizes the human relation, state, government, and society. The political sides are needs to understand as the social ruler. It means all humans life are organized from politics as political decision affects the entire human life. It also means that the state controls and regulates all other institution and association. That is why we all come within the control of the state. All important decisions about public life are taken by government. There are no sides in this world that are free from the political influences. Economics sides influence human life through the human wants and satisfaction. It is mainly concerned with the way in which a society chooses to employ its scarce resources which have alternative uses, for the production of goods for present and future consumption. The relation between society and government as the part of the state also can see in economics. Every person who runs a family is expected to make the best use of the income of the household. Similarly, the state is expected to get the maximum benefit for the society. It was the fact that the world has changed dynamism, always changed without control. The changed means entered to the world whereas the world feels become small and world become a global villages where everything information, modal, and culture moved vastly without limited access. As the result of the globalization, a capitalism system also found the existences. The capitalism system was known as economic system that is based on private ownership means of production and the creation of goods or services for profit. Capitalism entails the private ownership of the latter two natural resources and capital goods by a class of owners called capitalists. The capitalism system is one of the interesting parts to analyzing nowadays including in this thesis.

The previous researches which take the reflection of the global capitalism system as the topic has not been taken yet, but there are some researches which have a relevant topic and also take the data from The Hunger Games novel. First of all is Hemre in "Suzanne Collins' Hunger Games Trilogy and Social Criticism" (2013). Here, the writer analyzed the social construction of the Panem society in their daily life. The second is Loobeek in " $a$ Feminist Analysis of The Novel The Hunger Games (2012). In this research, the writer analyzed the appearance of feminism throughout The Hunger Games, especially when pertaining to the lead female character of Katniss Everdeen. The third is Stovall in "To kill a Mockingjay : an ideological criticism of The Hunger Games" (2015). Here, the writer analyzed the ideological criticism in the novel. The last is Aditiawarman in "Mitologisasi dalam novel The Hunger Games: Mockingjay part 1 (Analisis Semiotika Roland Bartes)" (2015). Here, the writer analyzed the myth aspects of the society in the novel by using semiotics analysis. The above four previous studies are different from the present study due to their aims. This study mainly deals with the reflection of the global capitalism system which is reflected through the story in Collins's The Hunger Games, and how the capitalism system affects their social life.

The researcher analyzed the different one. The researcher analyzed the reflection of the global capitalism system in The Hunger Games. The researcher becomes 


\section{9 | JURNAL ILMU BUDAYA}

Volume 6, Nomor 1, Juni 2018

the pioneer in Postgraduate of English Language Studies, Faculty of Cultural Sciences, Hasanuddin University who analyzes this novel of Suzanne Collins The Hunger Games. The researcher analyzes this novel by using sociology of literature approach which is acceptable with the object of this thesis. Thus, the research explores the new subject and object also perspective that is different from the previous researches.

This research aimed at finding out the reflection of the global capitalism system in The Hunger Games as revealed in the novel. Therefore the researcher decides the title of this journal is The Reflection of the Global Capitalism System in Suzanne Collins's The Hunger Games.

\section{METHODOLOGY}

\section{Type of Research}

In this study the researcher used descriptive and qualitative method, and to complete the analysis of this study, the researcher uses the sociology of literature approach. The focus of this study is to analyze the reflection of the global capitalism system which is reflected through the story in Suzanne Collins's The Hunger Games, and how the capitalism system affects their social life.

\section{Source of Data}

Moleung (1989) says that the writer acts as an instrument of data. In analyzing this study the researcher used the general sources which called primary and secondary data source. The primary data are collected from Suzanne Collins's The Hunger Games through the character and characterization, the plot and the setting of the story, and also from the descriptions and utterances which related to the research questions of this study. The secondary data are collected from the bibliographical data or referential data such as the various books, journals, articles, and another writings, both printed and electronics which possibly relevant to the subject matter of this research.

\section{Method of Collecting Data}

Endraswara (2013) states that the method of collecting data is one of the most important things in analyzing the study. This methodology consists of the rules of collecting and analyzing data in research which aimed to prove the theoretical answer. The researcher uses several steps in collecting data.

In analyzing the data of the chosen topic, the researcher used the object of the research. It is a novel by Suzanne Collins as a primary data in this research. Primary data is data which used to the main source in this discussion data were collected from the novel The Hunger Games. The primary data will collected by conducting careful reading of the text. Then the researcher will analyze and remember the important information from the text. In other case, the researcher also using books, pen, pencil and board marker as an instrument of the research in their function to support the primary data.

\section{Method of Analyzing Data}

In this research, the researcher used sociology of literature approach and descriptive qualitative method. The purpose of this method is to reveal the facts, situation, phenomenon, and the condition as what happened in the reality Furchan (2004). In analyzing this research, the researcher used the sociology of literature approach. The researcher reads the novel of Suzanne Collins's The Hunger Games, then applies the sociology of literature approach to analyze it. The analysis focuses on the reflection of the global capitalism system which is reflected through the story in Panem, and how the capitalism system affects their social life. In analyzing the data, the researcher uses the social interpretation. The researcher interprets all the data by connecting it with the social context. The other social issues which is related to the topic, biography and social life of the author are also analyzed more deeply. 


\section{0 | JURNAL ILMU BUDAYA}

Volume 6, Nomor 1, Juni 2018

\section{FINDINGS}

The researcher explains about the reflection of the global capitalism system in Panem. This analysis presents the capitalism phenomenon in social life of the country of Panem which is represented through the whole story in The Hunger Games.

\section{The Social Condition of the Society in Panem}

Collins (2015) explains that Panem was known as the representation of one country. The word Panem known comes from latin words. Panem has a number interpretation. It can be understand that sometimes people has a differences understanding about something. Panem likes a country with his structural organization. It was because Panem includes all the people, it makes social constriction also existed and stand in Panem. They have a President, and absolutely a leader in each district. Panem is located in North America and consists of the wealthy Capitol, which is surrounded by twelve poorer districts. The event known as the Hunger Games started after the districts had tried to rebel against the Capitol. During the rebellion, the 13th district was destroyed. When the Capitol had regained control of the districts in The Hunger Games were initiated as a punishment for the districts' rebellion. A boy and a girl between the ages of 12 and 18 are selected through lottery each year from each district to compete in the Hunger Games. The lottery is called "the reaping" and the day of the lottery is reaping day. There can only be one victor, one survivor. The games are televised and it is mandatory for the inhabitants in the districts to watch them.

When I was younger, I scared my mother to death, the things I would blurt out about District 12, about the people who rule our country, Panem, from the far-off city called the Capitol (Collins, 2008:7).

\section{E-ISSN: 2621-5101 P-ISSN:2354-7294}

The Panem consists of several districts. There were 13 district existed in the Panem but after rebellion, it was only 12 district left. Every district has a difference character and condition. These district represented likely provinces. The differences of condition and character in every district can be seen in the product or natural resources they have. It was likely in District 1 provides luxury items, District 7 provides lumber, District 11 grows food, District 12 mines coal. Katniss as the main character in the story stayed in District 12 . District 12 known as the coal mining and poor district.

\section{The Portrayal of Political and Economical in Panem}

Political rules which running by the ruler in Panem absolutely tricky and terrible. It was political repression as one on of the ways of capitalism system running also can be seen in The Hunger Games which is implemented by the Capitol Government. Capitol repressed the citizens in the districts in order to put down the rebellion. Government controls the mass media through censorship and propaganda. Capitol controls the citizen through the mass media which are television and books. Mass media and schools are primarily used for the sake of Capitol to give influence to the people in Panem. There was no democracy in Panem. It was only single government existed there. The president of the Panem does not choose from the people in every corner of the country but only from the conglomeration and the rich man in Capitol. Capitol, the ruling city of Panem is the only single party government in Panem. President Snow as the leader of government in Panem and also as the ruler of Panem has choosen only from rich people in Capitol.

This situation can be considered as the political strategy to maintain the power and the importance from people in Capitol. They did not want to lose their position and power. There was no mercy to the 


\section{1 | JURNAL ILMU BUDAYA}

Volume 6, Nomor 1, Juni 2018

people across twelve districts. The government only care about themselves and their colleague not to the people in districts. The rules which made only to maintain their power and political importance. Meanwhile, the government of Panem ruling economics side in terrible system and policy in many ways. The government control the economics activity through monopoly all resources and control the market value. Capitol controls every aspects of Panem including the economic. Capitol imposed very strict laws in the economy aspect. Every district should work hard and produce goods for Capitol and left nothing for the districts. People in the districts are forbidden to consume and enjoy their own production. It causes starvation and poverty has become a common thing in the districts.

\section{Global Capitalism System in Panem}

The global capitalism system in Panem can be seen in many sides and condition. These ideologies represented the differences between the position of the high class and lower class. The high class can be seen in the people in capitol when the lower class can be seen in every district. The capitol with their power always controls the district and making rules to them. The rule which was cannot disobey and fight against. When the rules break down, the peacekeeper will give hard punishment. The 13 districts of Panem resemble the 13 original colonies, founded by citizens fleeing from the oppression of Great Britain. The colonists faced economic, political, and social oppression by a ruling class that used taxation and unfair representation in the decision making process. The institutional forces of oppression follow the three previous themes: economic, political, and social. The relationship between the Capitol and the districts varies depending on the commodity item produced in the district and the need of the Capitol following a typical supply or demand relationship.

\section{E-ISSN: 2621-5101 P-ISSN:2354-7294}

\section{DISCUSSION}

\section{The Reflection of The Global Capitalism System in The Novel}

The capitalism system in Panem brings misery, injustice and terror to the people in every district. The district which feels more afflictions by the system was district 12. The condition as a poor district and people in starvation becomes the reason. The man should work at the coal mining day and night when women and children limited access to work and study. Those things more difficult as district 12 have no natural resources to manage. Even it existed, it's only in a few scale and they cannot free to manage it without permission from the Capitol. There are four aspects of capitalism system can be found in The Hunger Games. The first, single government is controlled by a dictator or ruling regime. The second, government controls the mass media through censorship and propaganda. The third, government control the economics activity through monopoly all resources and control the market value. The last, a central ideology controls every aspect of citizens' lives.

The first, single government is controlled by a dictator or ruling regime where in the state of Panem, there is no democracy. Capitol, the ruling city of Panem is the only single party government in Panem. What happen in the style of government system in Panem can be seen in reality. It means, some countries in the world taking the style of Panem, especially in the ideology of the leader in every country. In fact, some of the country's leaders were taking capitalism system as their patron to ruling the government policy. Make themselves strong influences and having power in money to claim the single party government across countryside or even in the world. The country in Europe and USA can be an example for these. They control the people in developing and poor country with their power in money, capitalism ideology and 


\section{2 | JURNAL ILMU BUDAYA}

Volume 6, Nomor 1, Juni 2018

politics (Kathryn, 2011). The second, government controls the mass media through censorship and propaganda. Capitol controls the citizen through the mass media which are television and books. Mass media and schools are primarily used for the sake of Capitol to give influence to the people in Panem. This kind of thing can be seen in the reality of the world. The government or the modal owner with their power and strong financial always tried to show up their power and dictated the people thought about their successful system. Like in Barry (1981) explains about the propaganda in politics that hiding bad news is the way to get a good impression. There is no negative news show up to the people in media, only the positive one. It can be understand that the government tried to build up the good impression to the people. Even though, the facts speak different.

The third, government control the economics activity through monopoly all resources and control the market value. Capitol controls every aspects of Panem including the economic. Capitol imposed very strict laws in the economy aspect. The last, a central ideology controls every aspect of citizens' lives. In this situation, the government may disseminate an ideology in the state. Cernak (2011) states that an ideology might be a political belief such as communism or fascism. In the novel, it is found that Capitol try to disseminate the ideology of their capitalism leader, President Snow. Snow has strict ideology in ruling Panem. The ideology of capitalism can be seen in the reality today. As what Samuelson (1983) says that "the industrial production of wealth, in which capital is responsible for the major portion of the wealth produced, and labor for only a small fraction of it". It can be seen when the government of the country dictated the market value and modal market. The government controls all of them while citizen only got a little. This method can be seen as in reflection of the way from the rich and influential countries to spread out their conspiracy theory. Here, the conspiracy theory means the method which used from the interest side to arrange formula to win the competition, control the target area, and take all profit from those things. It means, the natural resources becomes the hot commodity to taken and manage when the larger population becomes the best marketing target.

\section{CONCLUSION}

There was no people in the world can be live alone without any help, communication, and interaction with other people. It can be understand as the human wants and the role of social activity in the social life. All of human activities are affected by the interplay between social structure and each individual. The Hunger Games was a phenomenal novel which first published at the same year when America hit by crisis of financial in 2008. It can be seen in the novel, the story about young girl who lives in district 12 as the part side of Panem which was known as Katniss Everdeen. The leaders of Panem control the twelve districts from Capitol, the places where they live in. It can be seen that the leader showed their control of Panem with their game show which was known as The Hunger Games. These games taken a couple boy and girl from each district to fight with others 22 participants until there was only one survivors, one victor. The Hunger Games represented the global capitalism system in many ways. The differences between capitol and all district considered as the symbol of capitalism system. The capitol as the place of rich people, full of happiness, glamour while the district as the place for poor people, hopeless, uneducated, full of terror. The capitol as the ruler for all people and district in Panem can be easily control and dictated the people. They control the economic side, politic, market value with 


\section{3 | JURNAL ILMU BUDAYA}

Volume 6, Nomor 1, Juni 2018

their power. This is can be considered as the conspiracy theory that existed in the world where the rich country control and dictated the developing country and the poor country through economic, market value and also political side.

\section{BIBLIOGRAPHY}

Aditiawarman. 2015. Mitologisasi Dalam Novel The Hunger Games: Mockingjay part 1 (Analysis Semiotika Roland Bartes) (Skripsi). Jakarta. Universitas Mercu Buana.

Barry, Norman. 1981. An Introduction to Modern Political Theory. London. The Macmillan Company.

Cernak, Linda. 2011. Totalitarianism. Minnesota. Abdo Consulting Group

Collins, S. (2008). The Hunger Games. New York City. NY: Scholastic Press.

Endraswara, Suwardi. 2013. Metodologi Penelitian Sastra; Epistemologi, Model, Teori, dan Aplikasi. Yogyakarta. Center for Academic Publishing Service.

Furchan, Arief. 2004. Metode Penelitian Kualitatif Deskriptif. Jogyakarta. Pustaka Pelajar.

Hamre, K.T.H. 2013. Suzanne Collins' Hunger Games Trilogy and Social Criticism (Tesis). USA. University of Oslo.

Kathryn, Omsted S. 2011. Real Enemies: Conspiracy Theories and American Democracy, World War I to 9/11. New York. Oxford Univeresity Press.

Loobek, Kristi. 2012. A Feminist Analysis of The Hunger Games (Tesis). Canada. University St Paul.

Moleung, Lexy. 1989. Metodologi Penelitian Kualitatif. Bandung. Remaja Karya.

Samuelson, A. Paul. 1983. Foundation of Economics Analysis, Enlarged Edition. Boston. Harvard University Press.

\section{E-ISSN: 2621-5101 P-ISSN:2354-7294}

Stovall, Rene. 2015. To Kill A Mockingjay: An Ideological Critisism of The Hunger Games (Tesis). Texas. West Texas A\&M University. 